\title{
Study the Effect of a Polymerizable Surfactant on the Physico- Mechanical Properties of Natural Rubber (NR) and Styrene Butadiene Rubber (SBR)
}

\author{
D. E. El-Nashar*1, A.I. Khalaf ${ }^{1}$, A.M. Naser ${ }^{2}$, H. Abdel-Wahhab ${ }^{2}$, A.M. Ellaban ${ }^{1}$ \\ ${ }^{1}$ Department of Polymers and Pigments, National Research Centre, Dokki, Cairo, Egypt. \\ ${ }^{2}$ Faculty of Science, Al-Azhar University, Cairo, Egypt.
}

\begin{abstract}
D OLYMERIZABLE surfactant (methoxy polyethylene glycol methacrylate) (MPM) was synthesized by direct esterification reaction between (methoxy polyethylene glycol) and methacrylic acid and characterized by FTIR spectroscopy and proton nuclear magnetic resonance ('H NMR) spectroscopy. MPM was incorporated natural rubber (NR) and styrene butadiene rubber (SBR) and inspected as antioxidants for mixes vulcanizates to raise their resistant for ageing through storage to increase shelf life time. As well as possible to compare the effect of investigated (methoxy polyethylene glycol methacrylate) (MPM) with the commercial applied antioxidant in the production of rubber, as $(2,2,4$-trimethyl1,2-dihydroquinoline[TMQ]. The rheometric and physico mechanical properties of rubber mixes after and before thermal ageing were measured. The results obtained revealed that land 1.5 methoxy polyethylene glycol methacrylate (MPM) parts per 100 of rubber (phr) have superior effect in the protection of NR and SBR vulcanizates respectively.
\end{abstract}

Keywords: Polymerizable surfactant, Natural rubber, Synthetic rubber, Antioxidant, Ageing, Physico - mechanical properties.

\section{Introduction}

The aging of rubber is considered a huge problem. Through the process of aging little amounts of oxygen are absorbed by rubbers as (NR) and (SBR) or their vulcanizes. These lead to a major change in their physico-mechanical properties. Consequently it is important to incorporate antioxidants to rubber mixes to protect the rubber against oxidative degradation. Also to prolong the life of the rubber vulcanizates. While the performance of the antioxidants depends on many factors such as the rubber types, the aging types and kind of the ingredients of rubber mix. The antioxidants efficiencies also highly depend on their chemical structure. Generally Antioxidants can stabilize rubbers versus against heat and light aging. Polymers oxidation leads to crosslinking, chain scission, or produce oxygen which can form functional groups in the chains of polymers [1-3]. The derivative compounds of organo phosphorous, amines, phenols and organo sulfur are the major antioxidants. Generality formulation systems of rubber, alkoxy group are more effective for preventing long-term oxidative aging. The antioxidants compounds with low molecular weights leading to volatilize and surface bloom from the vulcanized rubber. So the using high molecular weight antioxidants compounds increase the persistence of the antioxidant in the rubber vulcanized which prevent the migration to the rubber surface and decrease volatilization [4-6]. Komethi et al. Study the aging of NR vulcanizates with natural antioxidant (NA) and commercial antioxidants (BHT) and (TMQ). This demonstrates that natural antioxidant can retard the oxidative aging in (NR) [7-8]. Bellas and coworker evaluated the oxidative degradation by a phenolic antioxidant which proves that these can protect the surface of (SBR) from aging [9-10].

The aim of the research is mainly to study the efficiency of (methoxy polyethylene glycol methacrylate) (MPM) as antioxidant for natural and synthetic rubbers (NR and SBR) to protect these rubbers from oxidative aging during use, storage and to prolong shelf life. Besides comparing their effect with the commercially applied antioxidant used in rubber industry, such as (2,2,4-trimethyl-1,2-dihydroquinoline) [TMQ]) . 


\section{Materials and Experimental}

Materials

Rubber

(i) Natural rubber (NR) was of the type (RSS-1) obtained from Transport and Engineering, Alexandria, Egypt, density of $0.913 \pm 0.005 \mathrm{~g} / \mathrm{cm}^{3}$ at $23{ }^{\circ} \mathrm{C}, \mathrm{Tg}=$ $-75^{\circ} \mathrm{C}$, and Mooney viscosity $\mathrm{ML}(1+4)$ at $100{ }^{\circ} \mathrm{C}$ $=60-90$.

(ii) Styrene-butadiene rubber: (SBR 1502 nonstaining) it has the following characteristics; styrene content $23.5 \%$ with specific gravity 0.945 , $\mathrm{Tg}=-60^{\circ} \mathrm{C}$ and Mooney viscosity ML $(1+4), 52$ \pm 3 at $100{ }^{\circ} \mathrm{C}$, was obtained from Transport and Engineering Company (TRENCO) Alexandria.

(iii) Accelerators: N-cyclohexyl-2-benzothiazole sulphenamide (CBS), a pale gray powder, with specific gravity of 1.27-1.31 at room temperature $\left(25 \pm 1^{\circ} \mathrm{C}\right)$, melting point $95-100^{\circ} \mathrm{C}$.

(iv) Antioxidants: (2,2,4-trimethyl-1,2dihydroquinoline [TMQ] was used as a commercial grade.

(v) Activators: Zinc oxide and stearic acid were used as activators with specific gravity at $15^{\circ} \mathrm{C}$ of 5.55-5.61 and 0.90-0.97, respectively.

(vi) Vulcanizing agent: Elemental sulfur, fine pale yellow powder, with specific gravity of 2.042.06 at room temperature.

(vii) Fillers: Silica (Hi-Sil 233D) of surface area $150 \mathrm{~m}^{2} / \mathrm{g}$, specific gravity 1.95 , particle size 15nm PPG Industries Inc., Netherlands, Europe.

(viii) Other chemicals: methacrylic acid, methoxypoly ethylenglycol, hydroquinone, sulfuric acid and Toluene were supplied by Sigma-Aldrich, Germany

\section{Synthesise and characterization of MPM}

The polymerisable surfactant (MPM) was synthesized as shown in Scheme 1 by direct esterification reaction between methoxy poly ethylenglycol and methacrylic acid. In $250 \mathrm{ml}$ 3- neck flask equipped with stirrer, condenser, thermometer and air inlet, $(0.02$ mole) of methoxy poly ethylenglycol was charged into the flask, the temperature was raised to $120{ }^{\circ} \mathrm{C}$ by using heating plate and the stirring rate was adjusted at $100 \mathrm{rpm}$, then add (0.02 mole) methacrylic acid (MAA), 0.2 gm hydroquinone (HQ 0.0018 mole) to prevent polymerization of meth acrylic acid in high temperature of esterification and $\mathrm{H}_{2} \mathrm{SO}_{4}(98 \%$ $\approx 0.01$ mole) as a catalyst is added then the reaction was allowed to proceed for $2 \mathrm{hrs}$ with stirring. Continuous stream of air is purged through flask to prevent polymerization of monomer via oxidation of hydroquinone to quinone. After the $2 \mathrm{hrs}$ the liberation of water was stopped and the reaction product was discharged, filtered and cooled. The synthesized polymerizable surfactant is dark yellow solids with melting points $82{ }^{\circ} \mathrm{C}$ which measured by electrothermal device [11]. The polymerisable surfactant (MPM) was characterized by Fourier transform infrared (FTIR) were recorded at room temperature using a Jascow FTIR-430 (Japan) and proton nuclear magnetic resonance ${ }^{1}$ HNMR was measured in dimethyl sulfoxide using BRUKER ECA $400 \mathrm{MHz}$ NMR spectrometer instrument.

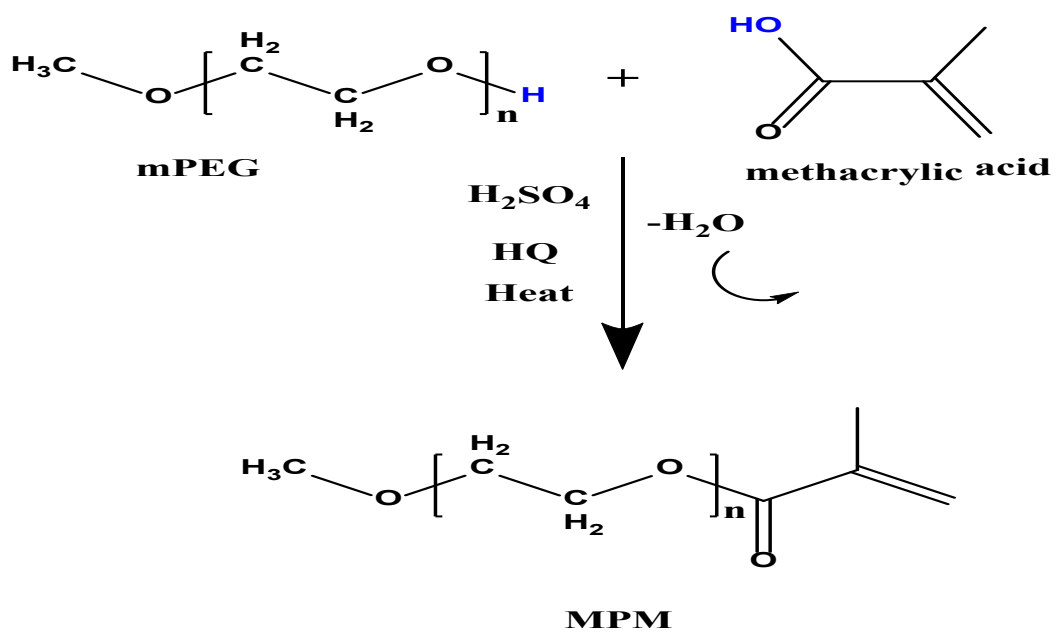

Scheme 1. Reaction between methoxy poly ethylenglycol (M-PEG) and methacrylic acid which produce methoxy polyethylene glycol methacrylate (MPM) and water.

Egypt.J.Chem. 61, No.1 (2018) 


\section{Experimental techniques}

Rubber was pre-mixed with all compounding ingredients according to ASTM: D3182-07 (2012). Mixing was done in a laboratory of two-roll mill. The speed of the slow roll is $24 \mathrm{rpm}$, with a gear ratio of 1:1.4. The compounded rubbers were left overnight before vulcanization. The vulcanization was carried out at $142 \pm 1^{\circ} \mathrm{C}$ for NR and $152 \pm 1^{\circ} \mathrm{C}$ for SBR in an electrically heated press under a pressure of about $4 \mathrm{MPa}$ to get vulcanized rubber sheets of (1-2) mm thickness.

\section{Rheometric characteristics}

$\mathrm{M}_{\mathrm{L}}$ (minimum Torque), $\mathrm{M}_{\mathrm{H}}$ (maximum Torque), $\mathrm{Tc}_{90}$ (optimum cure time), $\mathrm{Ts}_{2}$ (Scorch time), and cure rate index (CRI) were determined according to ASTM:D 2084-07 using a Monsanto oscillating disc rheometer model 100 (Akron, OH,USA). The measurements were carried out at $142 \pm 1$ and $152 \pm 1{ }^{\circ} \mathrm{C}$ for NR and SBR respectively.

\section{Mechanical properties}

Tensile strength, modulus at $100 \%$ and $200 \%$ elongation and elongation at break were measured at room temperature on a tensile testing machine (Zwick / Roell Z010) according to ASTM: D412-06.

\section{Swelling study}

A swelling test was carried out by soaking a specific weight of rubber samples in toluene at room temperature for $24 \mathrm{~h}$. The equilibrium swelling in toluene $(\mathrm{Q} \%)$ was determined according to the standard method (ASTM: D47106). The equilibrium swelling, $\mathrm{Q} \%$, could be calculated according to the following equation:

$$
\mathrm{Q} \%=\left[\left(\mathrm{w}_{\mathrm{s}}-\mathrm{w}_{\mathrm{d}}\right) / \mathrm{wd}\right] \times 100
$$

where $\mathrm{w}_{\mathrm{s}}$ is the weight of the swelled specimen and $\mathrm{w}_{\mathrm{d}}$ is the weight of the dried specimen.

\section{Thermal oxidative ageing}

The ageing process was carried out at $90 \pm 1 \mathrm{oC}$ in an air-circulating oven for different time periods according to ASTM: D 572-04, 2010. The reported results were averaged from a minimum five specimens.

\section{Results and Discussions}

Characterization of the polymerizable surfactant (MPM)

Fourier transform infrared (FTIR) spectroscopy Chemical composition of (MPM) sample can for instance be determined by Fourier transform infrared (FTIR) spectroscopy (Fig. 1).The peaks at $2885,1712,1466$ and $1111 \mathrm{~cm}^{-1}$ were associated with $\mathrm{C}-\mathrm{H}$ of alkane, $\mathrm{C}=\mathrm{O}$, and $\mathrm{C}=\mathrm{C}$ stretching frequencies of the methoxy polyethylene glycol moiety and MAA moiety, respectively. Broad band have a value at $3427 \mathrm{~cm}^{-1}$ characteristic for $\mathrm{C}-\mathrm{H}$ methylene and methine coupled with that of $\mathrm{OH}$ of $\mathrm{COOH}$ group and that of $\mathrm{H}_{2} \mathrm{O}$ [11].

\section{${ }^{1}$ HNMR Spectroscopy}

${ }^{1} \mathrm{HNMR}$ nuclear was measured in dimethyl sulfoxide using BRUKER ECA $400 \mathrm{MHz}$ spectrometer, at $400 \mathrm{MHz}$. Figure 2 shows the ${ }^{1}$ HNMR spectrum of the synthesized polymerizable surfactant MPM. The ${ }^{1}$ HNMR peak assignments are as follow, the three protons (1 Fig 2 ) of $\left[\mathrm{CH}_{3}-\mathrm{O}\right]$ appear at ppm 3.2, two protons of PEG moiety (2 Fig 2 ) of $\left[\mathrm{CH}_{3}-\mathrm{O}-\mathrm{CH}_{2}\right]$ appear at ppm 3.7 and two protons (3Fig 2 ) of $\left[\mathrm{O}-\mathrm{CH}_{2}-\right.$ $\mathrm{CH}_{2}-\mathrm{C}=\mathrm{O}$ ] appear at ppm 4.2 , while three protons (4 Fig 2 ) of $\left[\mathrm{CH}_{3}-\mathrm{C}=\mathrm{CH}_{2}\right]$ appear at ppm 1.8 and two protons (5 Fig 2 ) of $\left[\mathrm{CH}_{3}-\mathrm{C}=\mathrm{CH}_{2}\right]$ appear at ppm 5.6\&6.

Study the effect of MPM on rubber as antioxidants

Evaluation of the synthesized polymerizable surfactant on the physico-mechanical properties of NR vulcanizates

The (MPM) was incorporated in NR filled with (N2-N6) at different concentrations up to $2.5 \mathrm{phr}$. As well as comparing their effect with the commercial applied antioxidant in rubber products, as (2, 2, 4-trimethyl-1, 2-dihydroquinoline [TMQ] (N1) shown in Table 1.

\section{Rheological characteristics}

The rheometric characteristics of NR vulcanizates containing different concentrations of the prepared polymerizable surfactant were calculated and recorded in Table 2. It is noticed from this table that the minimum torque $\mathrm{M}_{\mathrm{L}}$, which reflects minimum viscosity of the mixes which did not significantly affected by adding 1 phrTMQ and $0.5 \mathrm{phr}$ MPM respectively but decreased and did not affected by increasing MPM concentrations (1-2.5). On the other hand the maximum torque $\mathrm{M}_{\mathrm{H}}$ was decreased by adding $1 \mathrm{phr}$ TMQ and $1 \mathrm{phr}$ MPM, then continually decreased with increasing MPM but did not significantly affect by adding 0.5 phr MPM. Also it is obvious that the enhancement in the rheometric properties of (NR) mixes due to reducing in the optimum cure time $\left(\mathrm{Tc}_{90}\right)$ and the raise in cure rate noticed index (CRI) can be noticed. As such, it can be said that this compound had an accelerating effect. This was noticed by the products of Datta et al. Abdelwahab et al. Abd 


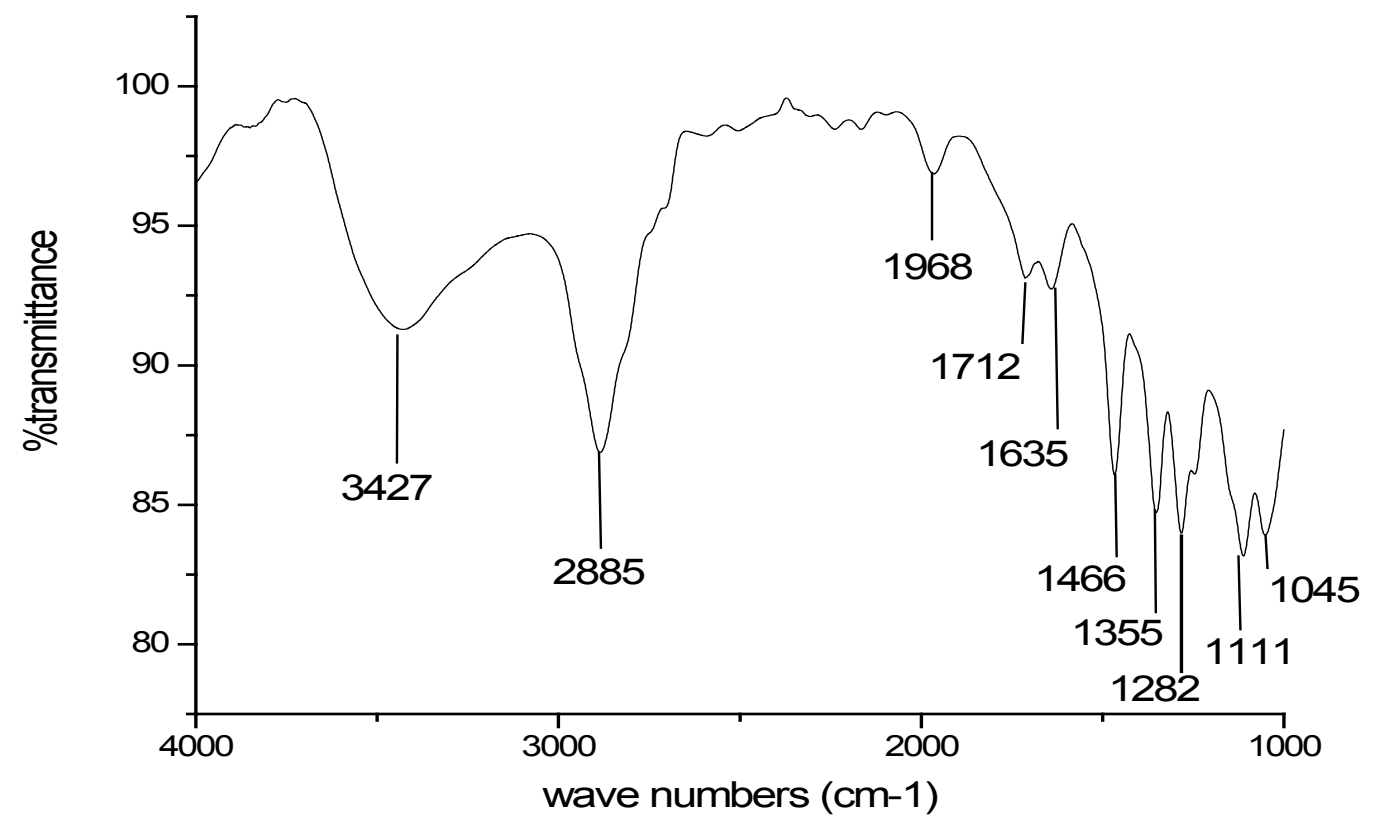

Fig. 1. FTIR for methoxy polyethylene glycol methacrylate (MPM).

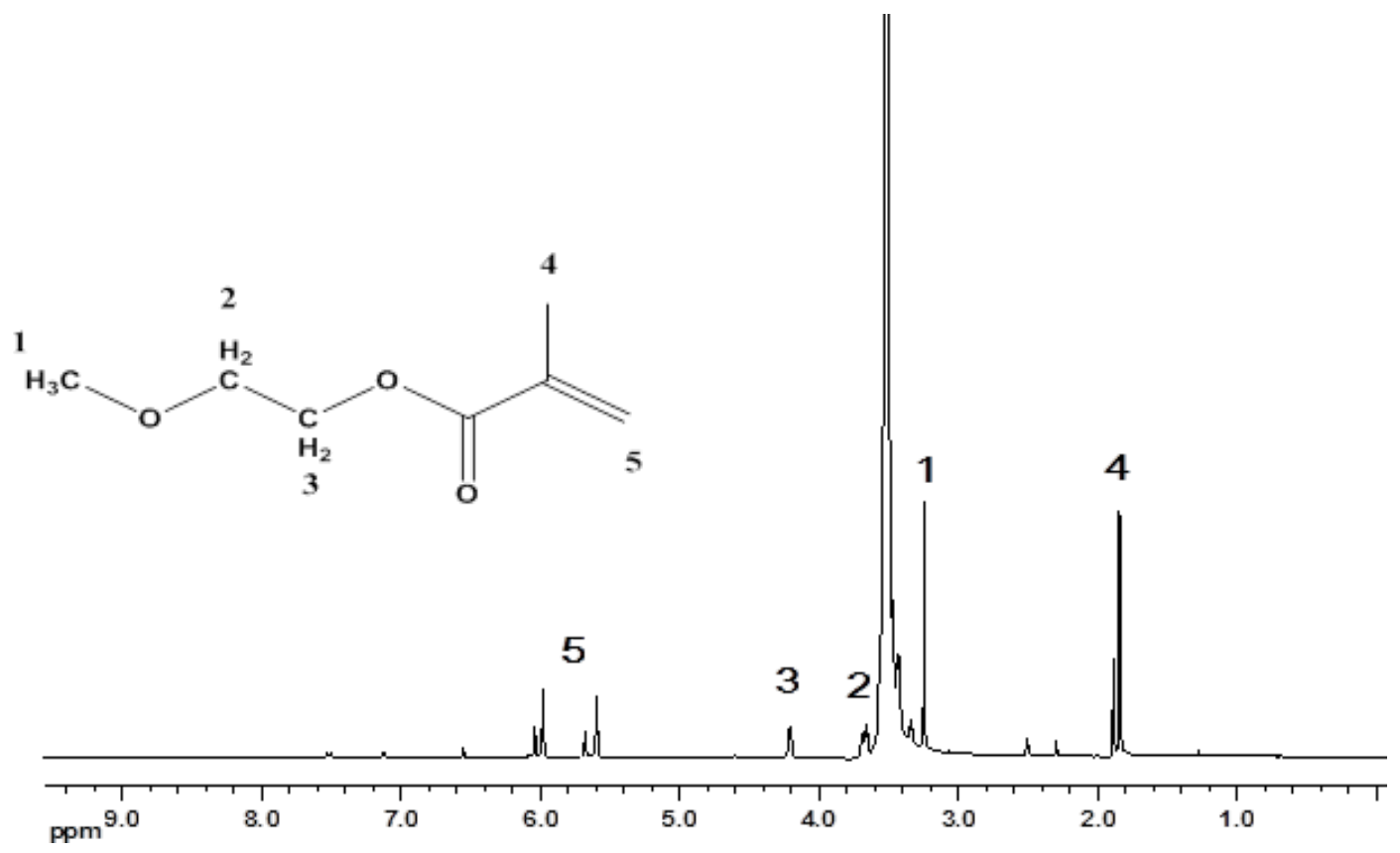

Fig. 2. ${ }^{1}$ HNMR Spectroscopy for methoxy polyethylene glycol methacrylate (MPM). 


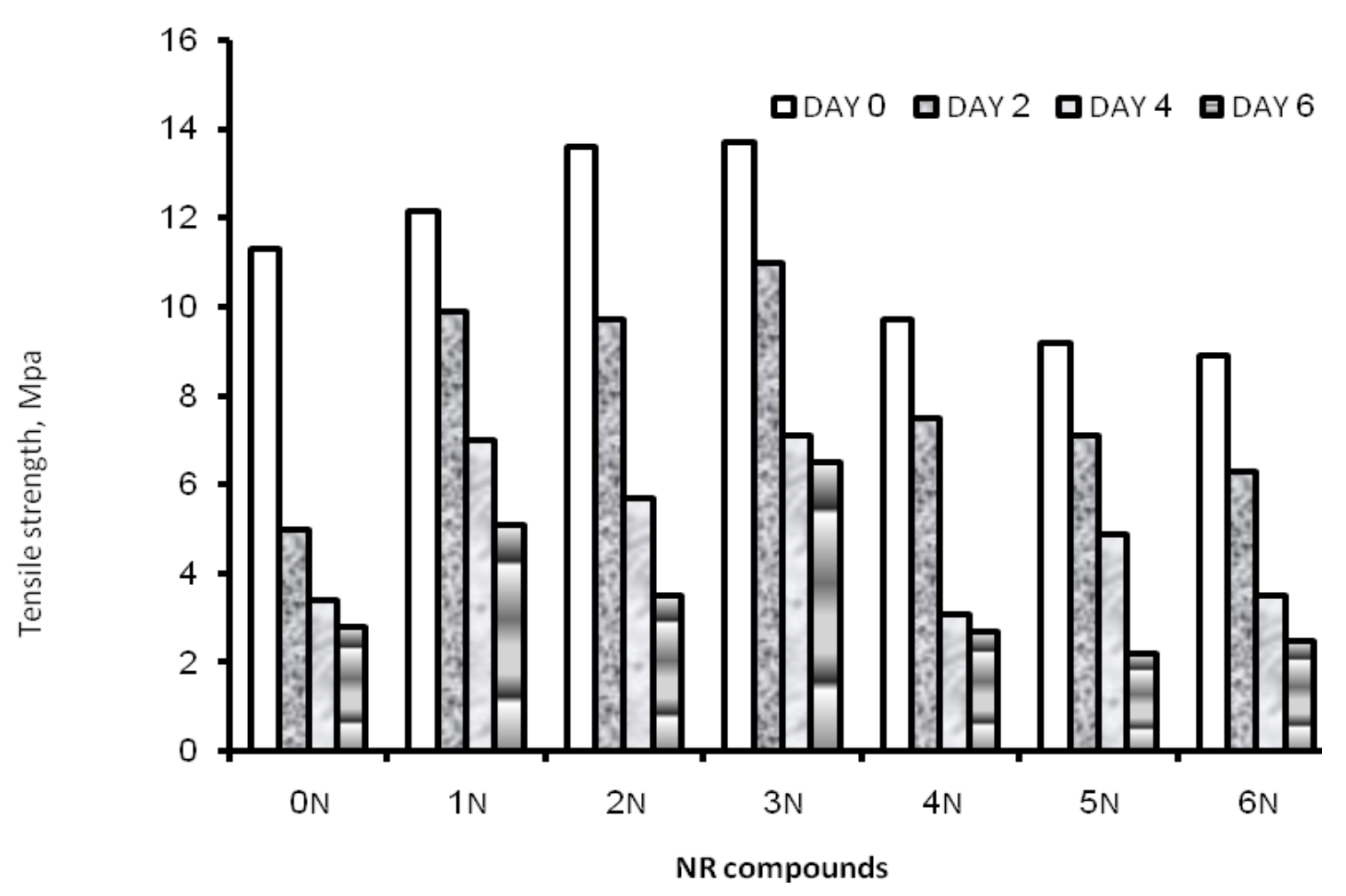

Fig. 3.The values of tensile strength.

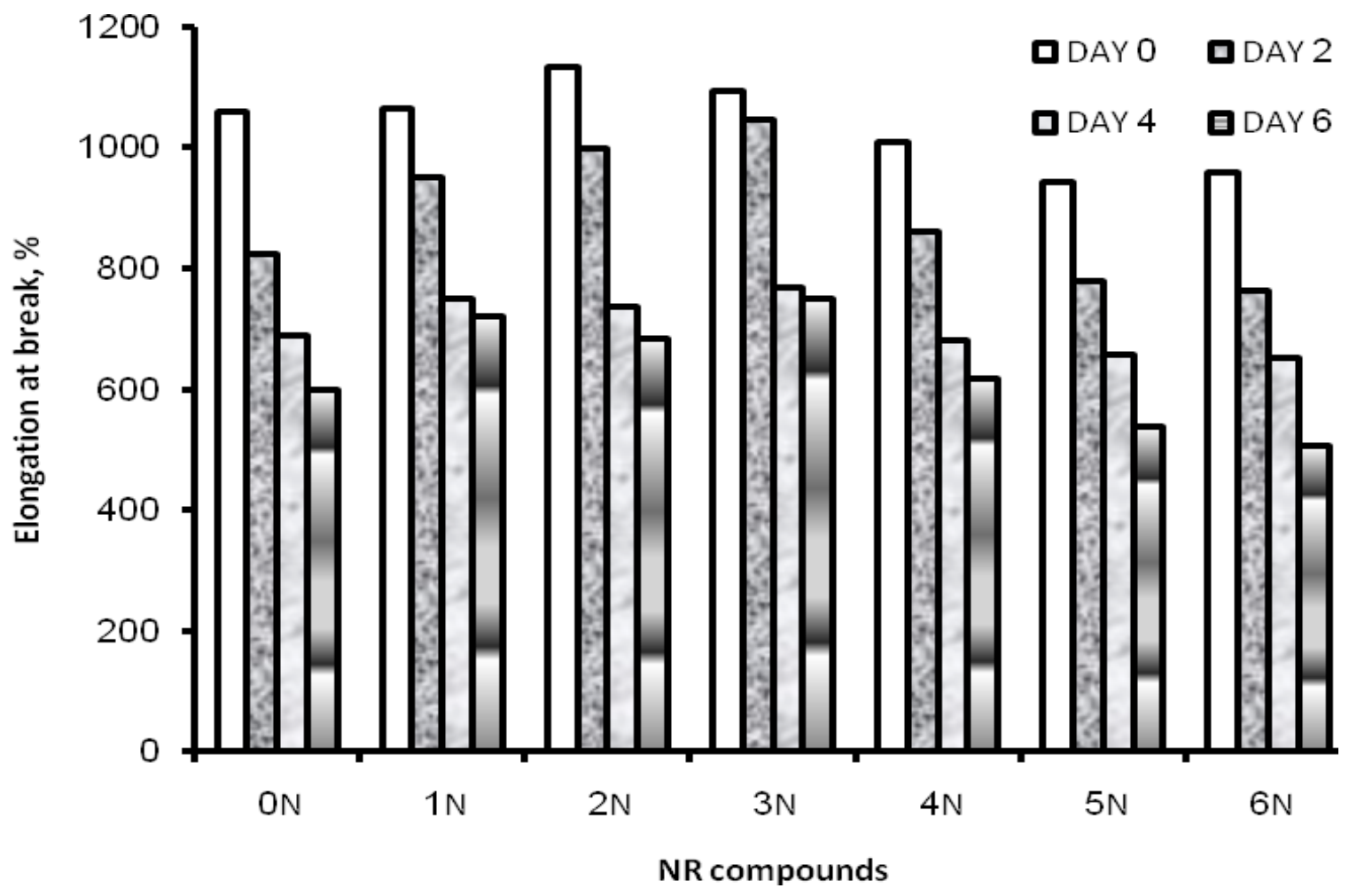

Fig. 4. The values of elongation at break $\%$. 


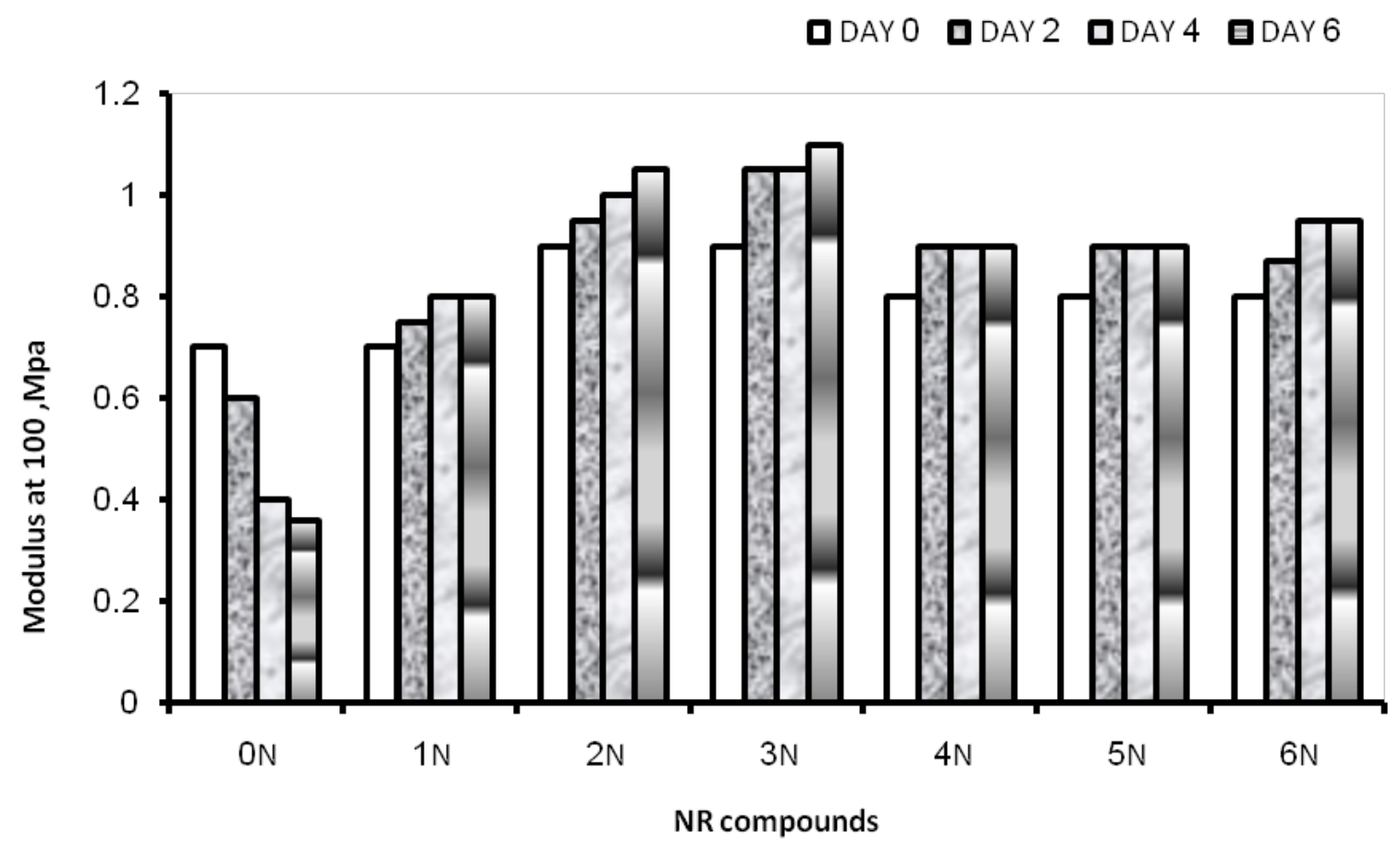

Fig. 5. The values of modulus at $100 \%$ elongation.

口DAYO $\boldsymbol{\square D A Y} 2$ वDAY 4 घDAY 6

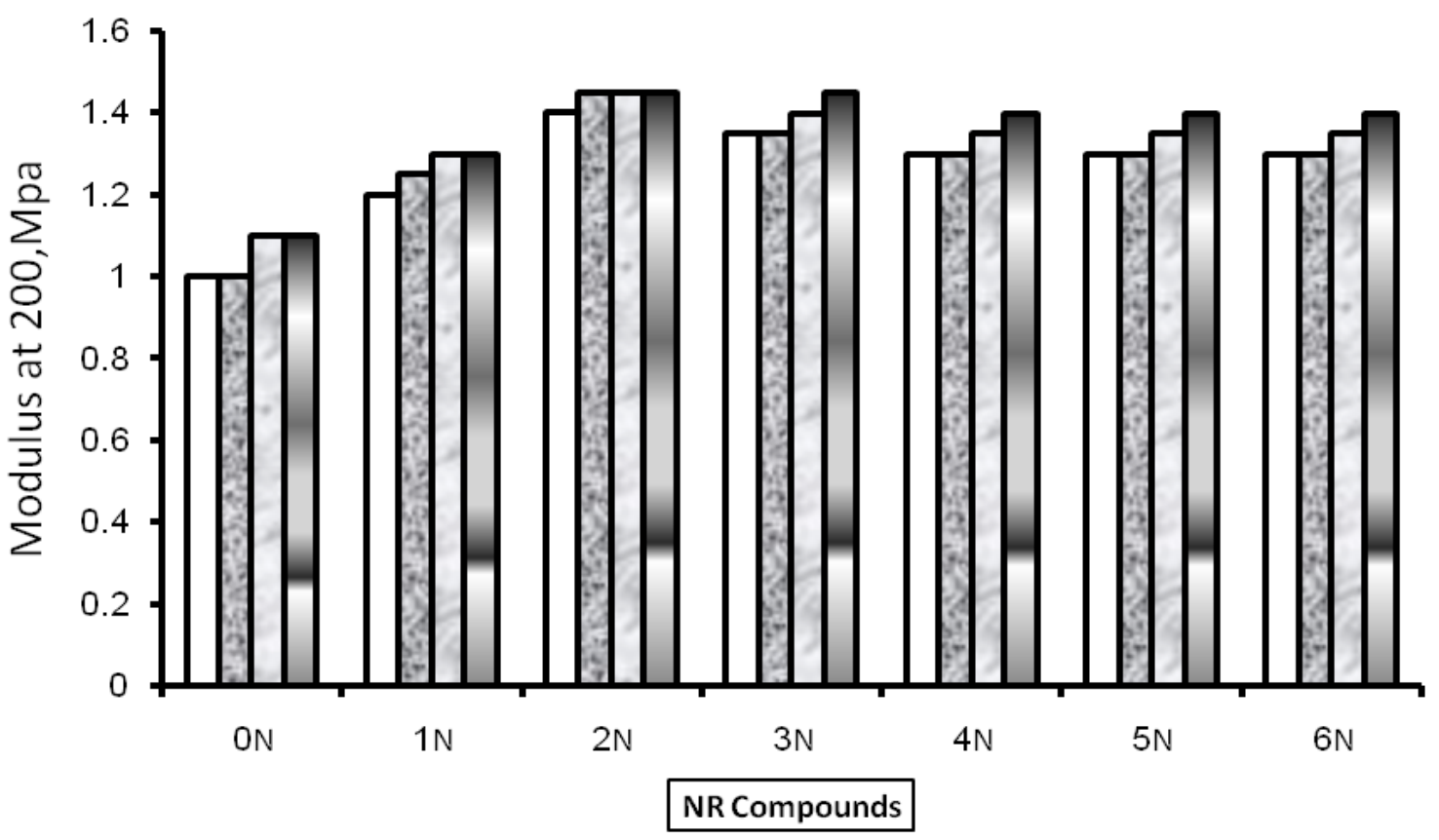

Fig. 6. The values of modulus at $200 \%$ elongation. 
TABLE 1. Natural rubber formulations containing the different concentrations of (MPM).

\begin{tabular}{|c|c|c|c|c|c|c|c|}
\hline $\begin{array}{c}\text { Sample no. ingredients } \\
(\mathrm{phr})\end{array}$ & $\begin{array}{c}\mathrm{N0} \\
\mathbf{0} \mathrm{phr}\end{array}$ & $\begin{array}{c}\mathrm{N1} \\
1 \mathrm{phr}\end{array}$ & $\begin{array}{c}\mathrm{N} 2 \\
0.5 \mathrm{phr}\end{array}$ & $\begin{array}{c}\mathrm{N3} \\
1 \mathrm{phr}\end{array}$ & $\begin{array}{c}\mathrm{N} 4 \\
1.5 \mathrm{phr}\end{array}$ & $\begin{array}{c}\text { N5 } \\
2 \mathrm{phr}\end{array}$ & $\begin{array}{c}\text { N6 } \\
2.5 \mathrm{phr}\end{array}$ \\
\hline Without antioxidant & - & - & - & - & - & - & - \\
\hline Antioxidant(TMQ) & - & 1 & - & - & - & - & - \\
\hline (MPM) & - & - & 0.5 & - & - & - & - \\
\hline (MPM) & - & - & - & 1 & - & - & - \\
\hline (MPM) & - & - & - & - & 1.5 & - & - \\
\hline (MPM) & - & - & - & - & - & 2 & - \\
\hline (MPM) & - & - & - & - & - & - & 2.5 \\
\hline
\end{tabular}

Base recipe: NR, 100; stearic acid, 2; zinc oxide, 5; Silica , 10 ; sulfur, 2; CBS,1.

TABLE 2. Rheometric characteristics and physico-mechanical properties of NR vulcanizates containing different concentrations of (MPM).

\begin{tabular}{|c|c|c|c|c|c|c|c|}
\hline Sample no. ingredients (phr) & $\begin{array}{c}\text { No } \\
\text { 0 phr }\end{array}$ & $\begin{array}{c}\text { N1 } \\
1 \mathrm{phr}\end{array}$ & $\begin{array}{c}\mathrm{N} 2 \\
0.5 \mathrm{phr}\end{array}$ & $\begin{array}{c}\text { N3 } \\
1 \mathrm{phr}\end{array}$ & $\begin{array}{c}\text { N4 } \\
1.5 \text { phr }\end{array}$ & $\begin{array}{c}\text { N5 } \\
2 \mathrm{phr}\end{array}$ & $\begin{array}{c}\text { N6 } \\
2.5 \mathrm{phr} \\
\end{array}$ \\
\hline \multicolumn{8}{|c|}{ Rheological characteristics at $142 \pm 1^{\circ} \mathrm{C}$} \\
\hline Minimum torque $\left(M_{\mathrm{L}}(\mathrm{dN})\right.$ & 1.5 & 1.5 & 1.5 & 1 & 1 & 1 & 1 \\
\hline Maximum torque $\mathrm{M}_{\mathrm{H}}(\mathrm{dN})$ & 53 & 48 & 53 & 48 & 45 & 43 & 33 \\
\hline Optimum cure time $\mathrm{Tc}_{90}(\mathrm{~min})$ & 8.75 & 8 & 7.5 & 6.5 & 6.5 & 6 & 5.5 \\
\hline Scorch time $\mathrm{Ts}_{2}(\mathrm{~min})$ & 4.5 & 4.25 & 3.25 & 2.75 & 2.55 & 2 & 1 \\
\hline Cure rate index CRI(min-1) & 23.53 & 26.66 & 23.53 & 26.66 & 25.3 & 25 & 22.22 \\
\hline \multicolumn{8}{|c|}{ Physical and mechanical properties at $\mathbf{T C}_{90}$} \\
\hline Tensile strength (MPa) & 11.3 & 12.15 & 13.6 & 13.7 & 9.7 & 9.2 & 8.9 \\
\hline Modulus at $100 \%$ strain $(\mathrm{MPa})$ & .7 & .7 & .9 & .9 & .8 & .8 & .8 \\
\hline Modulus at $200 \%$ strain (MPa) & 1.0 & 1.2 & 1.4 & 1.35 & 1.3 & 1.3 & 1.3 \\
\hline Elongation at break $(\%)$ & 1060 & 1065 & 1134 & 1095 & 1008 & 942 & 959 \\
\hline Equilibrium swelling (\%) & 344 & 342 & 324 & 322 & 333 & 335 & 340 \\
\hline
\end{tabular}

El-Ghaffar et al. Khalaf et al. and Youssef et al [12-16]. Table 2 shows the natural rubber mixes which vulcanized to their $\mathrm{T}_{\mathrm{C} 90}$ at $142 \pm 1{ }^{\circ} \mathrm{C}$ and submitted to accelerate thermal oxidative aging at $90 \pm 1{ }^{\circ} \mathrm{C}$ for various time up to 6 days.

Mechanical properties

The physical and mechanical properties of NR vulcanizates were tabulated in Table 2 . It observed that the values of tensile strength were increased with incorporation of TMQ and prepared MPM up to $1 \mathrm{phr}$ this is due to the increasing of crosslinks density between NR chains, and then decreased with increasing MPM concentration. The proof of this finding is the increase in tensile modulus at 100 and $200 \%$ Elongation. On the other hand the values of elongation at break and equilibrium swelling were slightly affected by incorporation of TMQ and prepared MPM. From the Table 2, it can be seen the sample containing $1 \mathrm{phr}$ (MPM) has higher strength at break, modulus, and elongation at break which compared to the sample without antioxidant, TMQ and the samples containing the different concentrations of (MPM).

Influence of MPM as anti-thermal aging on the NR vulcanizates

There is no doubt that rubber products used as engineering materials due to their unique collection of elastic and viscous features. The thermal aging of rubbers represented the highest problems in rubber products due to the small amount of oxygen which absorbed and causes change in physical and mechanical properties of rubbers [17]. NR vulcanizates which containing different concentrations of the prepared MPM were displayed to thermal aging at $90 \pm 1^{\circ} \mathrm{C}$ for various times up to 6 days. Figures.3-6 illustrate the relation between the values of strength at 
break, modulus at $100 \%$ and $200 \%$, and elongation at break and the time of aging for samples which containing TMQ and MPM. The figures show that the sample N0 (without antioxidant) had lower strength at break, modulus at $100 \%$ and $200 \%$, and elongation at break than the other samples incorporated with the MPM or TMQ. It can be observed that the MPM protected at $1 \mathrm{phr}$ which has the highest efficiency as this is due to the electron donating of the methoxy $\left(-\mathrm{OCH}_{3}\right)$ group .The principle requirements for majority of the antioxidant are the presence of labile hydrogen in their chemical structure.

Study the effect of the synthesis (MPM) compound on the SBR vulcanizates

Table 3 shows the formulations of SBR containing TMQ and different concentrations of (MPM) up to $2.5 \mathrm{phr}$.

\section{Rheological characteristics}

Table 4 shows the Rheological and physicomechanical properties of the SBR formulations. It is obvious from Table 4, that the MPM decreased the cure time $\left(\mathrm{Tc}_{90}\right)$ and increased (CRI). This illustrates that this compound had an accelerating action. As well it is noticed from Table 4 that the (MPM) compound increases the tensile strength, elongation at break and modulus $100 \%$ and $200 \%$ elongation while they slightly decrease the equilibrium swilling. From these results, the investigated polymerizable surfactant MPM can act as antioxidant in styrene butadiene rubber vulcanizates. This is may be the existence of reactive center methoxy group (OCH3) in the (MPM) structure. So it can be concluded that MPM is an interesting antioxidant for SBR vulcanizates. Table 4 shows the SBR mixes which vulcanized to their $\mathrm{T}_{\mathrm{C} 90}$ at

TABLE 3. SBR formulations containing the different concentrations of (MPM).

\begin{tabular}{|c|c|c|c|c|c|c|c|}
\hline Sample no. ingredients (phr) & $\begin{array}{c}\mathrm{B}_{0} \\
\text { 0 phr }\end{array}$ & $\begin{array}{c}\mathrm{B}_{1} \\
1 \mathrm{phr}\end{array}$ & $\begin{array}{c}\mathrm{B}_{2} \\
0.5 \mathrm{phr}\end{array}$ & $\begin{array}{c}\mathrm{B}_{3} \\
1 \mathrm{phr}\end{array}$ & $\begin{array}{c}\mathrm{B}_{4} \\
1.5 \mathrm{phr}\end{array}$ & $\begin{array}{c}\mathrm{B}_{5} \\
2 \mathrm{phr}\end{array}$ & $\begin{array}{c}\mathrm{B}_{6} \\
2.5 \mathrm{phr}\end{array}$ \\
\hline Without antioxidant & - & - & - & - & - & - & - \\
\hline Antioxidant(TMQ) & - & 1 & - & - & - & - & - \\
\hline (MPM) & - & - & 0.5 & - & - & - & - \\
\hline (MPM) & - & - & - & 1 & - & - & - \\
\hline (MPM) & - & - & - & - & 1.5 & - & - \\
\hline (MPM) & - & - & - & - & - & 2 & - \\
\hline (MPM) & - & - & - & - & - & - & 2.5 \\
\hline
\end{tabular}

Base recipe: SBR, 100; stearic acid, 2; zinc oxide, 5; Silica, 10; sulfur, 2; CBS,1;

TABLE 4. Rheometric characteristics and physico-mechanical properties of SBR vulcanizates containing the prepared different concentrations of (MPM).

\begin{tabular}{|c|c|c|c|c|c|c|c|}
\hline Sample no. ingredients (phr) & $\begin{array}{c}\mathrm{B}_{0} \\
\text { 0 phr }\end{array}$ & $\begin{array}{c}\mathrm{B}_{1} \\
1 \mathrm{phr}\end{array}$ & $\begin{array}{c}\text { B }_{2} \\
0.5 \text { phr }\end{array}$ & $\begin{array}{c}\mathrm{B}_{3} \\
1 \mathrm{phr}\end{array}$ & $\begin{array}{c}B_{4} \\
1.5 \\
\text { phr }\end{array}$ & $\begin{array}{c}B_{5} \\
2 \mathrm{phr}\end{array}$ & $\begin{array}{c}\text { B }_{6} \\
2.5 \text { phr }\end{array}$ \\
\hline \multicolumn{8}{|c|}{ Rheological characteristics at $152 \pm 1{ }^{\circ} \mathrm{C}$} \\
\hline Minimum torque $\left\{\mathrm{M}_{\mathrm{L}}\right\}(\mathrm{dN})$ & 10.0 & 7.5 & 11 & 10.0 & 6.0 & 3 & 3 \\
\hline Maximum torque $\mathrm{M}_{\mathrm{H}}(\mathrm{dN})$ & 41.5 & 38.5 & 46 & 46 & 45 & 38 & 36 \\
\hline Optimum cure time $\mathrm{Tc}_{90}(\mathrm{~min})$ & 16.5 & 16 & 15 & 13.5 & 12.75 & 10.75 & 10 \\
\hline Scorch time $\mathrm{Ts}_{2}(\mathrm{~min})$ & 9 & 10.25 & 8 & 8.5 & 8.5 & 6 & 5 \\
\hline Cure rate index CRI(min-1) & 13.3 & 17.4 & 14.3 & 20 & 23.5 & 21.05 & 20 \\
\hline \multicolumn{8}{|c|}{ Physical and mechanical properties at $\mathrm{TC}_{90}$} \\
\hline Tensile strength $[\mathrm{Mpa}]$ & 3.06 & 5.5 & 4.9 & 5.0 & 7.2 & 3.9 & 3.6 \\
\hline Modulus at $100 \%$ strain $[\mathrm{MPa}]$ & 0.93 & 1.10 & 1.10 & 1.15 & 1.20 & 1.10 & 1.10 \\
\hline Modulus at $200 \%$ strain $[\mathrm{MPa}]$ & 1.30 & 1.50 & 1.50 & 1.60 & 1.70 & 1.50 & 1.50 \\
\hline Elongation at break (\%) & 556 & 862 & 843 & 738 & 937 & 762 & 673 \\
\hline Equilibrium swelling (\%) & 325 & 328 & 323 & 307 & 305 & 310 & 314 \\
\hline
\end{tabular}

Egypt.J.Chem. 61, No.1 (2018) 
$152 \pm 1{ }^{\circ} \mathrm{C}$ and displayed to accelerate thermal oxidative aging at $90 \pm 1{ }^{\circ} \mathrm{C}$ for various time up to 6 days. [18-21]. the SBR vulcanizates

Figures 7-10 show the physico-mechanical properties of SBR vulcanizates as strength at break, modulus at $100 \%$ and $200 \%$, and elongation at break against the aging time. It is concluded that investigated MBM compound is highly efficient antioxidant than the commercial antioxidant (TMQ). It is noticed that $1.5 \mathrm{phr}$ is the optimum dose of investigated MBM
Influence of MPM as anti-thermal aging on

compound to give good physico-mechanical properties due to the presence of $(-\mathrm{OCH} 3)$ group.

\section{Conclusion}

- The synthesized compound can act as high efficient antioxidants in natural rubber and styrene butadiene rubber vulcanizates comparing with TMQ, which is a commercial antioxidant.

- The optimum phr for the synthesis compound (methoxy polyethylene glycol methacrylate) (MPM) mixed in natural and styrene

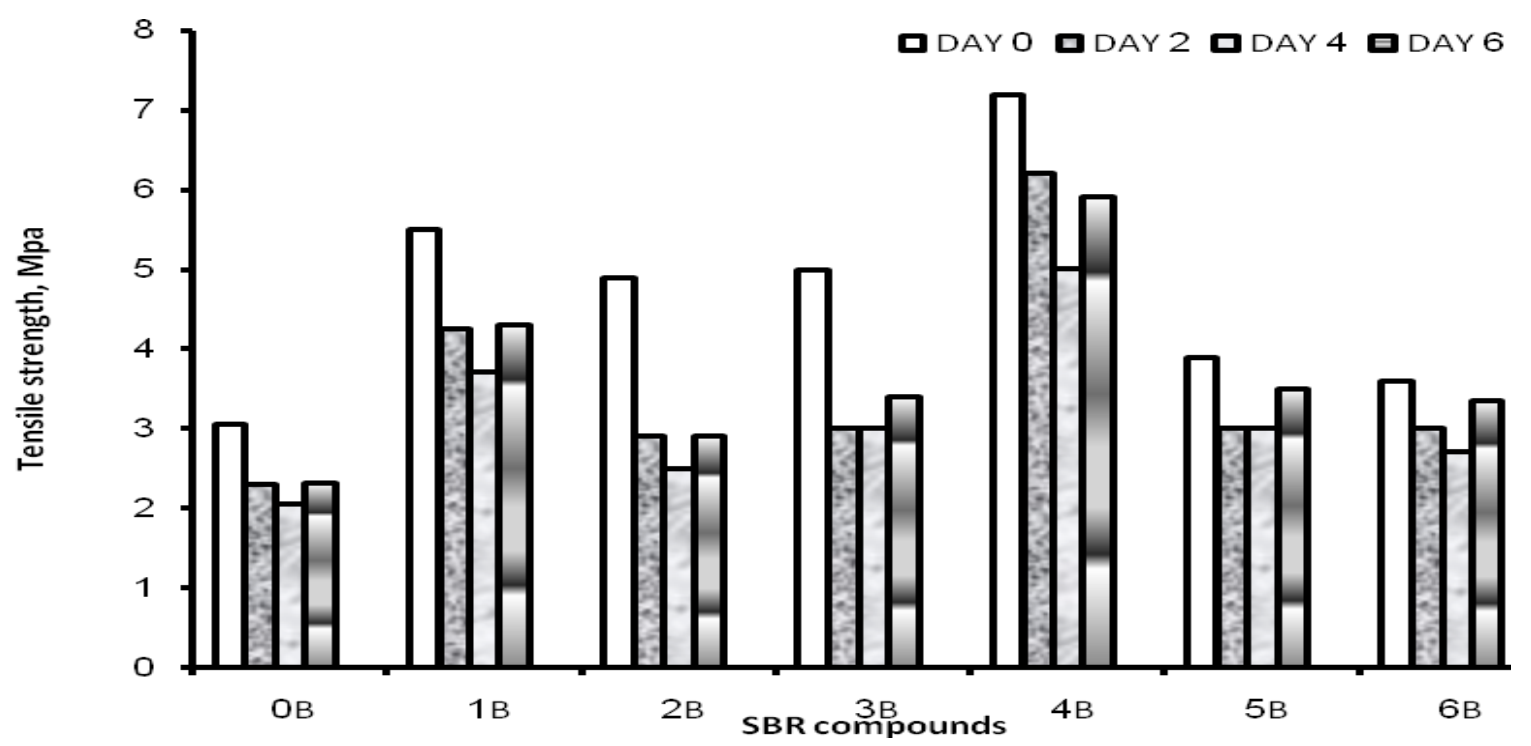

Fig. 7. The values of tensile strength.

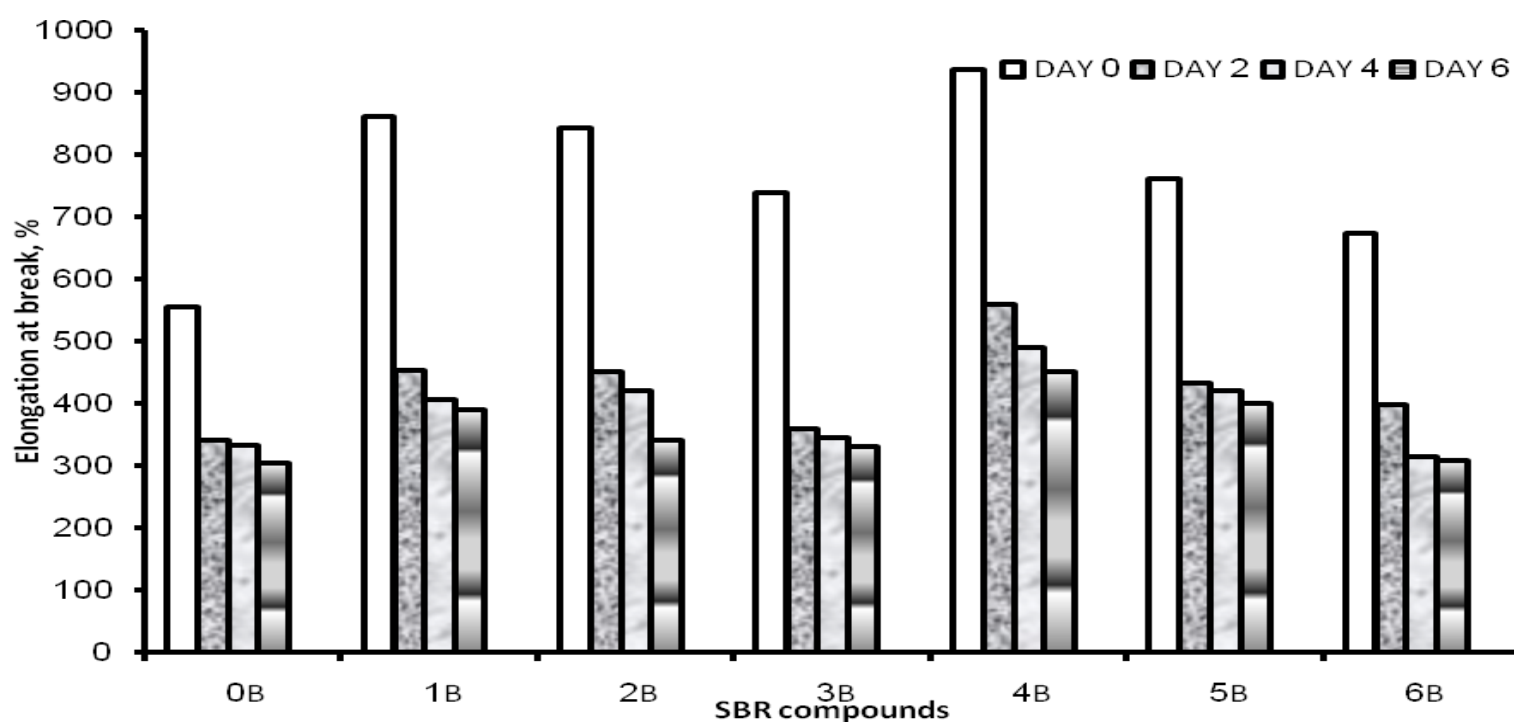

Fig. 8. The values of elongation at break. 


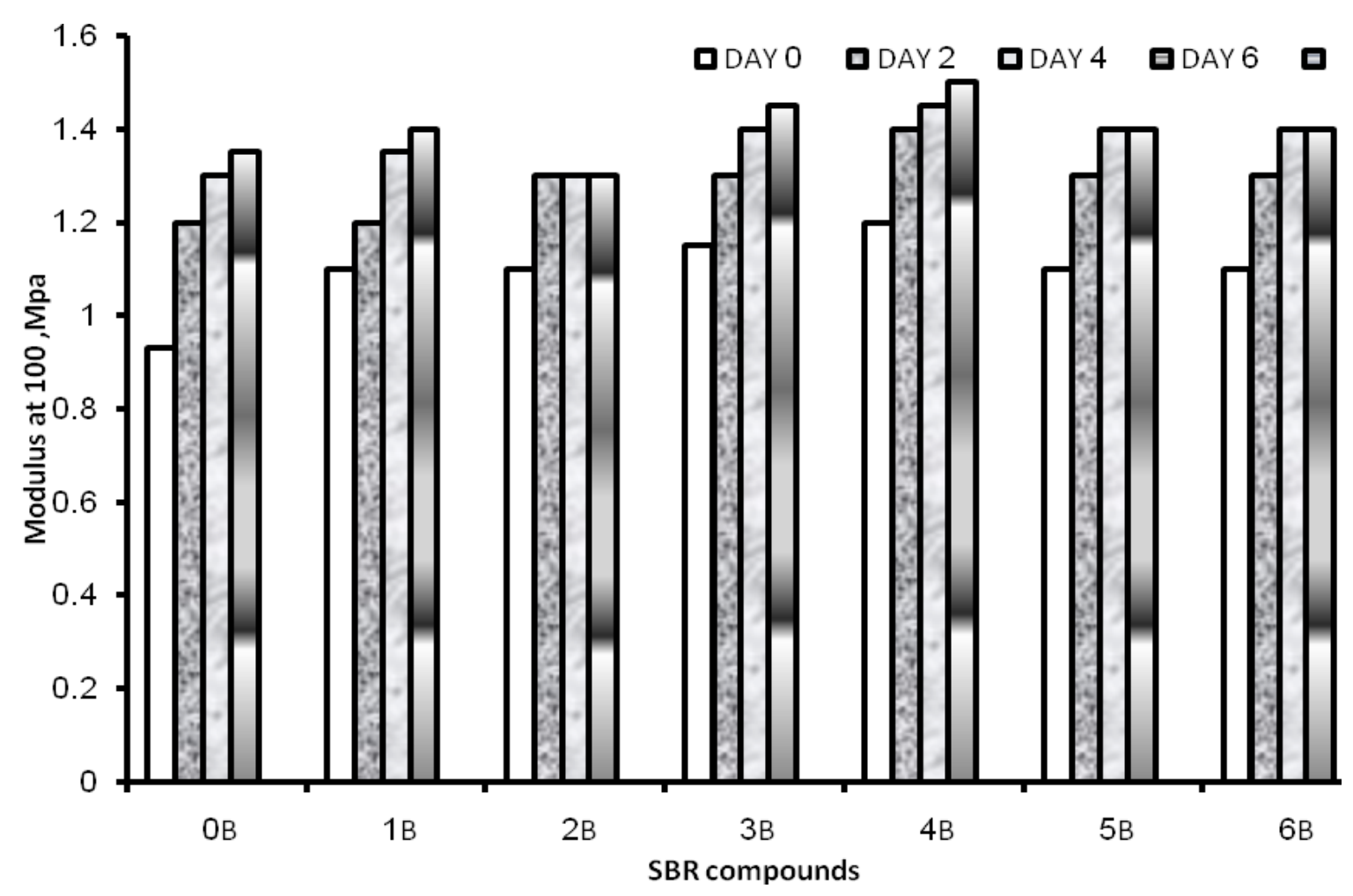

Fig. 9. The values of modulus at $100 \%$ elongation.

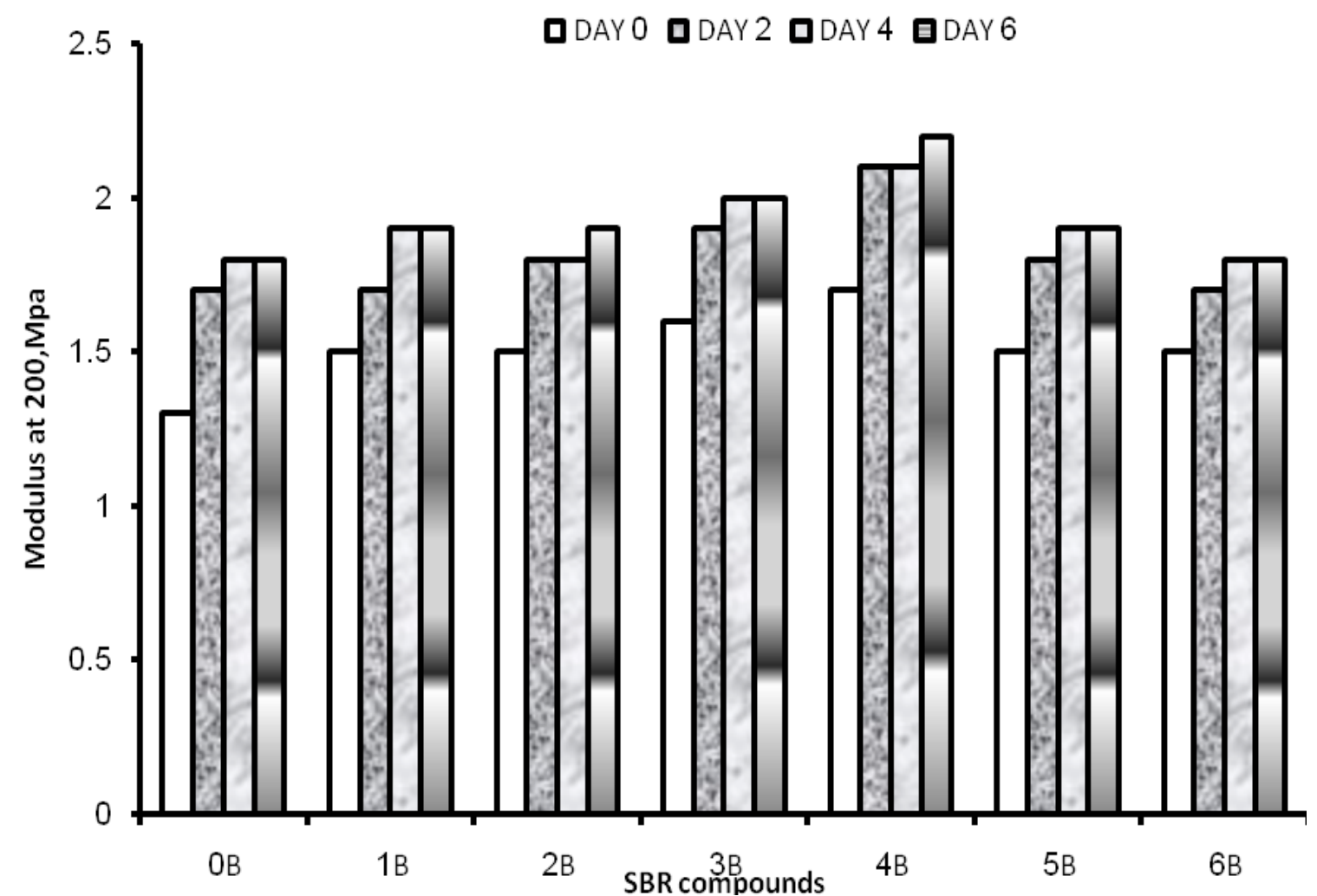

Fig. 10. The values of modulus at $200 \%$ elongation. 
butadiene rubber mixes which contained 1 and $1.5 \mathrm{phr}$ respectively if compared with TMQ.

\section{References}

1. Al-Malaika, S., Mechanisms of antioxidant action and stabilization technology - the aston experience. Polym. Degrad. Stab. 34(1), 1-36 (1991).

2. Barnard D. and Lewis P.M., In Natural Rubber Science and Technology, ed by A.D. Roberts. Oxidative Ageing pp. 621-675, (Oxford University Press, Oxford, 1988).

3. Abad L.V., Relleve L.S., Aranilla C.T., Aliganga A.K., San Diego C.M. and dela Rosa A.M., Natural antioxidants for radiation vulcanization of natural rubber latex. Polym. Degrad. Stab. 76, 275-279 (2002).

4. Pan J.Q., Liu N.C. and Lau W.W.Y., Synthesis and properties of new polymerizable antioxidants. Polym. Degrad. Stab. 62, 315-322 (1998).

5. Wazzan A.A., Ismail M.N. and Abd El-Ghaffar M.A., Evaluation of some polyaromatic amines asantirads and antifatigue agents in SBR vulcanizates. Int. J. Polym. Anal. Charact. 10(1), 57-69 (2005).

6. Youssef E.A.M., El-Nashaar D. and Abd ElGhaffar M.A., Evaluation of itaconic acid aromatic diamine adducts as novel antioxidants polymers. Part 1: evaluation as antioxidants for natural rubber vul-canizates. Pigm. Resin Technol. 32, 219-234 (2003).

7. Komethi M., Othman N., Ismail H. and Sasidharan S., Comparative study on natural antioxidant as an aging retardant for natural rubber vulcanizates, $J$. Appl. Polym Sci.124, 1490(2012).

8. Zhang H. and Liu K., The synthesis of novel Schiff base antioxidants to promote anti-thermal aging properties of natural rubber. Chemical Papers 71(8), 1481-1489 (2017).

9. Bellas R., Diez J., Rico M., Barral L., Ramirez C. and Montero B., Accelerated ageing of styrenebutadiene rubber nanocomposites stabilized by phenolic antioxidant. Polym. Compos. 35(2), 334343(2014).

10. Mahir N.A., Ismail H. and Nadras O., Tensile, swelling and thermal aging properties of Mangosteen (GarciniaMangostana) peel powder filled natural rubber compounds, Journal of Poly. Mat., 33(1), 233-243 (2016).

11. El-Kousya S. M., Youssef Y. A., Hassan W. A., Tawila M.A. and Basuni M.M., Synthesis,
Characterization and Aqueous Properties of a polymerisable nonionic surfactant exposure. RJPBCS, 7(5)2650 (2016).

12. Datta R.N., Huntink N.M., Datta S. and Talma A.G., Rubber vulcanizates degradation and stabilization. Rubber Chem. Technol. 80, 436480 (2007)

13. Abdelwahab N.A., El-Nashar D.E. and Abd ElGhaffar M.A., Polyfuran, polythiophene and their blend as novel antioxidants for styrene-butadiene rubber vulcanizates. Mater. Des. 32, 238-245 (2011).

14. Abd El-Ghaffar M.A., El-Nashar D.E. and Youssef E.A.M., Maleic acid/phenylenediamine adducts as new antioxidant amide polymers for rubber (NR and SBR) vulcanizates. Polym. Degrad. Stab. 82(1), 47-57 (2003)

15. Khalaf A.I., Helaly F.M. and El-Sawy S. M., Effect of chitosan derivatives as rubber antioxidants for increasing durability. Res.Chem. Intermed. 40,1383-1401(2014).

16. Youssef E.A.M., El-Nashaar D.E. and Abd El-Ghaffar M.A., Evaluation of itaconic acid/ aromatic diamine adducts as novel antioxidants. Polymers, 32(4), 219-234(2003).

17. Ismail H. and Mahir N.A., Study of mangosteen (garciniamangostana) peel powder as antioxidant in natural rubber compound, Vinyl \& Additive Tech. 23(2), 86-92 (2017).

18. Nawwar G.A.M., Yakout E.M.A., El-Sadiek M.S.A. and El-Sabbagh S.H., Synthesis and evaluation of new antioxidants for styrene butadiene rubber. Pigm. Resin Technol. 40(6), 399-409 (2011).

19. Shehata A.B.A. Nasr and Farouk T., Effect of some polymeric phenolic antioxidants on the properties of SBR vulcanizates, Polymer-Plastics Technology and Engineering, 44,1281-1295 (2005).

20. Abd El-Ghaffar M.A., El-Nashar D.E. and Youssef E.A.M., Evaluation of maleic acid / phenylenediamine adducts as new antioxidant amide polymers for rubber (NR and SBR) vulcanizates. Polymer Degradation and Stability, 82(1), 47-57 (2003).

21. Visakh P.M., Monti M., Puglia D., Rallini M., Santulli C., Sarasini F., Thomas S. and Kenny J.M., Mechanical and thermal properties of crab chitin reinforced carboxylated SBR composites. Express Polym. Lett. (5), 396-409 (2012).

(Received 14/1/2018; accepted 4/2/2018)

Egypt.J.Chem. 61, No.1 (2018) 


\section{دراساه تأثثر العامل الاستحلابي المتبلمر علي خواص المطاط الطبيعي ومطاط الاستيرين بيوتاداين ت بائن}

دعاءعصام النشار'، أماني إبراهيم خلف'، عبدالرحمن مختارناصرّ، حماده عبدالوهاب ابراهيمץ، أيمن

'قسم البلمر ات و المخضبات ـ المركز القومي للبحوث ـ القاهرة ـ مصر ، بقسم الكيمباء ـ كلية العلوم ـ جامعة الاز هر ـ القاهرة

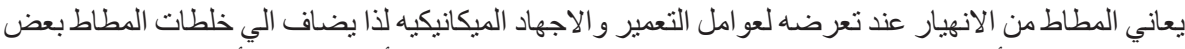

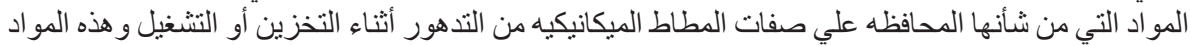

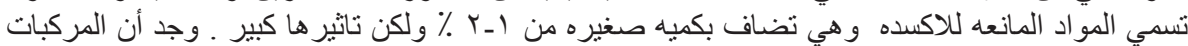

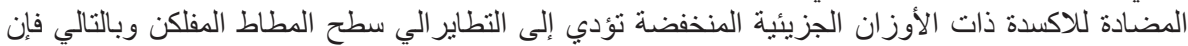

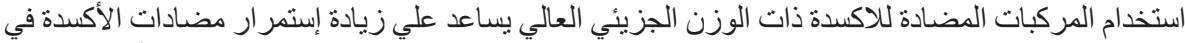

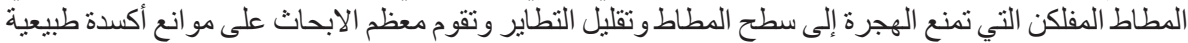

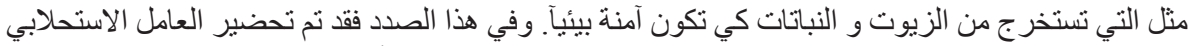

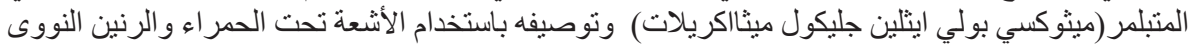

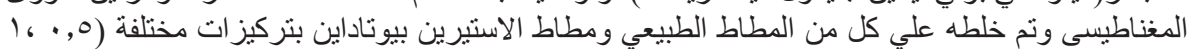

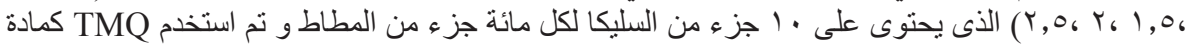

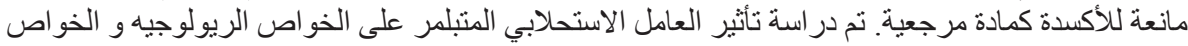

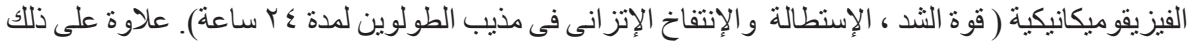

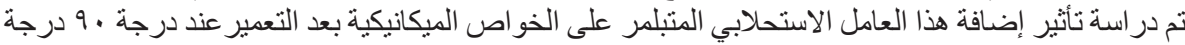

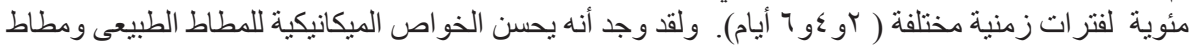

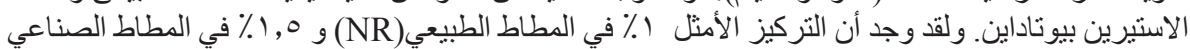

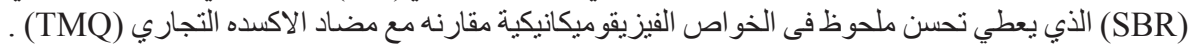

